\title{
The Cyclobutanocucurbit[5-8]uril Family: Electronegative Cavities in Contrast to Classical Cucurbituril while the Electropositive Outer Surface Acts as a Crystal Packing Driver
}

\author{
Minghua Chen ${ }^{1}\left[\right.$, Naixia Lv ${ }^{1}$, Weiwei Zhao ${ }^{2}$ and Anthony I. Day ${ }^{3, *(1)}$ \\ 1 College of Biology and Chemistry, Xingyi Normal University For Nationalities, Xingyi 562400, China; \\ gui_zhou_chen@163.com (M.C.); xiaoxia791102@163.com (N.L.) \\ 2 Pharmaron Beijing Co., Ltd., Beijing 100176, China; kingzhao@yeah.net \\ 3 Chemistry, School of Science, University of New South Wales Canberra, Australian Defence Force Academy, \\ Canberra, ACT 2600, Australia \\ * Correspondence: a.day@adfa.edu.au; Tel.: +61-5-114-5041
}

check for updates

Citation: Chen, M.; Lv, N.;

Zhao, W.; Day, A.I. The

Cyclobutanocucurbit[5-8]uril Family:

Electronegative Cavities in Contrast

to Classical Cucurbituril while the Electropositive Outer Surface Acts as a Crystal Packing Driver. Molecules 2021, 26, 7343. https://doi.org/ $10.3390 /$ molecules 26237343

Academic Editor: Afang Zhang

Received: 26 October 2021

Accepted: 30 November 2021

Published: 3 December 2021

Publisher's Note: MDPI stays neutral with regard to jurisdictional claims in published maps and institutional affiliations.

Copyright: (c) 2021 by the authors. Licensee MDPI, Basel, Switzerland. This article is an open access article distributed under the terms and conditions of the Creative Commons Attribution (CC BY) license (https:// creativecommons.org/licenses/by/ $4.0 /)$.

\begin{abstract}
The structural parameters for the cyclobutanoQ[5-8] family were determined through single crystal X-ray diffraction. It was found that the electropositive cyclobutano methylene protons $\left(\mathrm{CH}_{2}\right)$ are important in forming interlinking crystal packing arrangements driven by the dipoledipole interactions between these protons and the portal carbonyl $\mathrm{O}$ of a near neighbor. This type of interaction was observed across the whole family. Electrostatic potential maps also confirmed the electropositive nature of the cyclobutano $\mathrm{CH}_{2}$ but, more importantly, it was established that the cavities are electronegative in contrast to classical Q[5-8], which are near neutral.
\end{abstract}

Keywords: cyclobutanocucurbituril; cucurbituril; dipole interactions; electronegative cavities; molecular host

\section{Introduction}

Cucurbit $[n]$ uril (classical $Q[n], n=5-8,10$, and 13-15) have been shown to exhibit a wide range of potential applications in various fields, through leveraging the properties of this macrocyclic family and by the selection of a cavity with an appropriate size. Recent examples demonstrate this with targeted cell imaging [1], human cancer assay [2], Q[n]-based supramolecular frameworks (QSFs) [3,4], sensors [5-8], fluorescent imprintable hydrogels [9], fluorescent probes [10-12], nitroxide radical probes [13], the preparation of adsorbent or solid fluorescent materials [14], room-temperature phosphorescence (RTP) [15,16], light-harvesting systems [17], nanocapsules [18], nanofiltration membranes [19] molecular machines [20-22] reductive catalysis of $\mathrm{CO}_{2}$ [23], and gold recovery [24].

A bank of fully substituted derivatives of $\mathrm{Q}[n]$ have slowly emerged in the literature between 1992-2017, where the equatorial regions have been decorated with methyl $(\mathrm{Me})$, hydroxyl $(\mathrm{OH})$ groups, or the fused rings cyclohexano $(\mathrm{CyH})$, cyclopentano $(\mathrm{CyP})$, and cyclobutano $(\mathrm{CyB})$ (Figure $1, \mathrm{R}_{n} \mathrm{Q}[n]$ ) [25-30]. The alkyl-substituted examples are all synthesized by the $\mathrm{H}^{+}$/cat. condensation and oligomerization of an appropriately substituted glycoluril with $\mathrm{HCHO}$ or from its diether alone. However, bearing Me or $\mathrm{CyH}$ substituents only favors the formation of the smaller homologues $n=5$ (major) and 6 [25-27]. Significantly, the contracted rings, especially CyB, enable the formation of higher homologues $n=7$ and $8[29,30]$. Just prior to our reporting of the synthesis of the fully substituted $\mathrm{CyB}_{8} \mathrm{Q}[8]$ the partially substituted $\mathrm{Me}_{4} \mathrm{Q}[8]$ and $\mathrm{CyH}_{2} \mathrm{Q}[8]$ were the only higher homologues $(n=8)$ carrying substitution that are prepared by condensation and cyclo-oligomerization (Figure 1, bottom $\mathrm{R}_{x} \mathrm{Q}[n]$ ) [31]. 


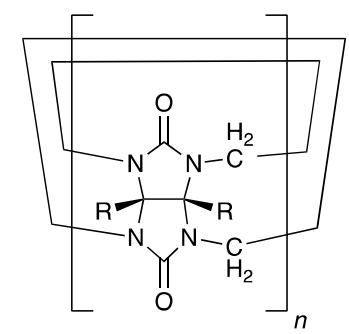

$\mathrm{R}_{n} \mathrm{Q}[n]$
$\mathrm{R}=\mathrm{Me}, \mathrm{OH}$, and

rings $-\left(\mathrm{CH}_{2}\right)_{4},\left(\mathrm{CH}_{2}\right)_{3},\left(\mathrm{CH}_{2}\right)_{2}$ (CyH, CyP, CyB respectively)

Classical $\mathrm{Q}[n] \quad \mathrm{R}=\mathrm{H}$

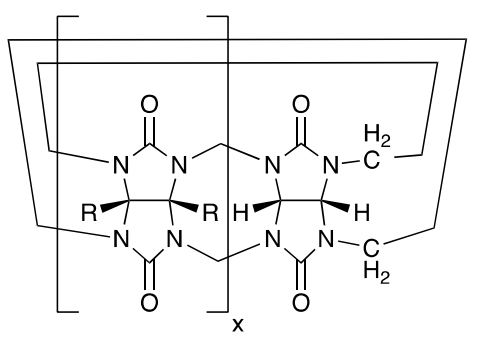

$\mathrm{R}_{x} \mathrm{Q}[n]$

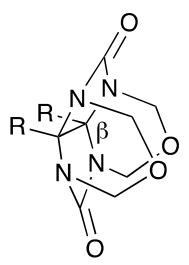

Glycoluril diether

Figure 1. Classical $Q[n]$ is represented above, where all $\mathrm{R}=\mathrm{H}$ (top LHS). Fully substituted derivatives $\mathrm{R}_{\mathrm{n}} \mathrm{Q}[n]$ are shown for the five known examples (top LHS). Partially substituted derivatives are $\mathrm{R}_{\mathrm{x}} \mathrm{Q}[n]$ (bottom). Glycoluril diether identifying the $\beta^{\circ}$ angle is discussed in the text (RHS).

The motivation for examining the contracted ring substituents $\mathrm{CyP}$ and then $\mathrm{CyB}$ related to a hypothesis that the dihedral angle, $\beta^{\circ}$, of the fused imidazolidinone rings at the concave face was an important contributor to the formation of higher homologues. This was especially relevant to the synthesis of fully substituted higher homologues, which were otherwise unavailable. As a follow-up to the previous work, we included theoretical calculations for the angle $\beta^{\circ}$ for each of the precursor glycoluril diethers $(\mathrm{R}=\mathrm{Me}, \mathrm{CyH}$, $\mathrm{CyP}, \mathrm{CyB}$, Figure 1). Using this theory, the angle for each was not only available to compare to measured values as a verification but also to provide calculated values, which would otherwise not be available.

Herein, we report a repeat of the initial synthesis of $\mathrm{CyB}_{5-8} \mathrm{Q}[5-8]$ with the objective of obtaining crystal structures for each of the homologues [30]. This not only provides support for the original findings but also enables the collection of important structural data to better understand possible influences on their physical and chemical properties. Particularly relevant is the diameter of the cavities and the portal openings in comparison to homologues of classical $\mathrm{Q}[n]$ and/or different substitutions.

In solution, it was previously observed that equatorial substitution has an effect upon the binding affinities of various molecular guests, where affinities can increase or decrease relative to the same guest molecule [20-22,29-32]. In the case of partially substituted derivatives such as $\mathrm{Me}_{4} \mathrm{Q}[6]$ and $\mathrm{Me}_{4} \mathrm{Q}[8]$ (Figure 1, bottom), a distortion in the cavity can partly explain a change in the binding affinity, which is also dependent upon the guest's shape [20-22,31], whereas, with full substitution, the $Q$ cavities are spheroidal and effects upon binding affinities in solutions can best be explained by electronic changes, the degree of $Q$ structure rigidity, and variations in diameters of the portals and cavities. Two significant examples that demonstrate this were previously reported for comparative binding affinities for classical $\mathrm{Q}[6]$ and $\mathrm{CyP}_{6} \mathrm{Q}[6]$ (Figure 1) for the guest ions cyclohexylammonium and octane-1,8-diammonium, respectively, 120- and 8-fold higher in the latter host [20]. The explanation for the increase is primarily related to an increase in electron density on the carbonyl O contributed by the equatorial alky substituents [21].

In addition to the physical dimensions, electronic surface effects in the solid state were reported by Tao and coworkers for classical $\mathrm{Q}[n]$ crystal packing. They found a strong interactive correlation between the electropositive outer surface of Qs with a neighboring 
Q electronegative portal and/or anions, in particular, the anion $\left[\mathrm{ZnCl}_{4}\right]^{2-}$ or similar large anions [3].

The objectives in this study were to determine the physical and electronic similarities or differences between $\mathrm{CyB}_{5-8} \mathrm{Q}[5-8]$ and classical $\mathrm{Q}[n]$.

\section{Results and Discussion}

We were fortunate in being able to obtain single crystals of all four homologues with suitable quality for $\mathrm{X}$-ray diffraction. The $\mathrm{CyB}_{5} \mathrm{Q}[5]$ was obtained in the first crop of crystals from acidic water $(\sim 0.05 \mathrm{M})$ as $\mathrm{CyB}_{5} \mathrm{Q}[5] \cdot 7 \mathrm{H}_{2} \mathrm{O}(\mathbf{1})$. The second crop of crystals from the same solution, which at this point had become more concentrated due to evaporation, afforded $\mathrm{CyB}_{6} \mathrm{Q}[6]$ as $\mathrm{CyB}_{6} \mathrm{Q}[6] \cdot 2 \mathrm{Cl}^{-} \cdot 2\left(\mathrm{H}_{3} \mathrm{O}^{+}\right) \cdot 14 \mathrm{H}_{2} \mathrm{O}(2)$. The remaining two homologues, $\mathrm{CyB}_{7} \mathrm{Q}[7]$ and $\mathrm{CyB}_{8} \mathrm{Q}[8]$, were concentrated into product-rich fractions by silica gel chromatography of the residue obtained from the filtrate after the collection of the co-crystallized $\mathrm{CyB}_{5-6} \mathrm{Q}[5-6]$. $\mathrm{CyB}_{7} \mathrm{Q}[7]$ was crystallized from dilute $\mathrm{HCl}$ as $\mathrm{CyB}_{7} \mathrm{Q}[7] \cdot 12 \mathrm{H}_{2} \mathrm{O}(3)$, while the crystallization of $\mathrm{CyB}_{8} \mathrm{Q}[8]$ was facilitated with the addition of $\mathrm{ZnCl}_{2}$ in dilute $\mathrm{HCl}$ to afford $\mathrm{CyB}_{8} \mathrm{Q}[8] \cdot\left(\mathrm{ZnCl}_{3} \cdot \mathrm{H}_{2} \mathrm{O}\right)^{-} \cdot \mathrm{H}_{3} \mathrm{O}^{+} \cdot 10 \mathrm{H}_{2} \mathrm{O}$ (4).

The first notable feature of the family of $\mathrm{CyB}_{5-8} \mathrm{Q}[5-8]$ was the similarity in their dimensions to the classical Q[5-8] family. A comparison to a selection of reported guest free classical Q[5-8] showed that the average dimensions of the portals, cavities, and depths were indiscernible from those of $\mathrm{CyB}_{5-8} \mathrm{Q}[5-8]$ (Table 1).

Table 1. A comparison of the dimensions of CyB5-8Q[5-8] to classical Q[5-8] derived from X-ray crystal structures.

\begin{tabular}{|c|c|c|c|}
\hline $\mathrm{Q}[n]$ & Portal O-O Average Diam & Cavity C-C Average Diam & $\begin{array}{c}\text { Depth } \\
\stackrel{\AA}{A}\end{array}$ \\
\hline $\mathrm{Q}[5]$ & 2.11 & 5.22 & 9.13 [33] \\
\hline $\mathrm{CyB}_{5} \mathrm{Q}[5]$ & 2.15 & 5.22 & 9.13 \\
\hline $\mathrm{Q}[6] \mathrm{Na}$ & 3.80 & 6.80 & $9.08[34]$ \\
\hline $\mathrm{CyB}_{6} \mathrm{Q}[6]$ & 3.96 & 6.77 & 9.15 \\
\hline $\mathrm{Q}[7]$ & 5.17 & 8.20 & 9.09 [33] \\
\hline $\mathrm{CyB}_{7} \mathrm{Q}[7]$ & 5.21 & 8.22 & 9.13 \\
\hline Q[8] & 6.91 & 9.79 & 9.13 [35] \\
\hline $\mathrm{CyB}_{8} \mathrm{Q}[8]$ & 6.99 & 9.76 & 9.16 \\
\hline
\end{tabular}

Dimensions include van der Waals radii.

Another important feature found with the $\mathrm{CyB}_{5-8} \mathrm{Q}[5-8]$ family in their crystal packing arrangement is the interaction of the outer equatorial surface of $\mathrm{CyB}_{n} \mathrm{Q}[n]$ and electronegative portal $\mathrm{O}$ and/or anions. This was found with the $\mathrm{Cl}^{-}$anion in the case of the crystal of $\mathrm{CyB}_{6} \mathrm{Q}[6] \cdot 2 \mathrm{Cl}^{-} \cdot 2\left(\mathrm{H}_{3} \mathrm{O}^{+}\right) \cdot 14 \mathrm{H}_{2} \mathrm{O}(2)$ and the $\left[\mathrm{ZnCl}_{3} \mathrm{H}_{2} \mathrm{O}\right]^{-}$anion in the case of the crystal of $\mathrm{CyB}_{8} \mathrm{Q}[8] \cdot\left(\mathrm{ZnCl}_{3} \cdot \mathrm{H}_{2} \mathrm{O}\right)^{-} \cdot \mathrm{H}_{3} \mathrm{O}^{+} \cdot 10 \mathrm{H}_{2} \mathrm{O}(4)$.

In this context, we calculated the ESP maps for each of the $\mathrm{CyB}_{n} \mathrm{Q}[n]$ homologues. Compared to similar electrostatic potential maps (ESP) for the classical Q[5-8] there were two distinct differences [3b]. The outer equatorial surface was less positive by 10-12 $\mathrm{kcal} \mathrm{mol}^{-1}$ compared to ESPs for the classical Q[5-8], however, clearly sufficiently positive, favoring interactions with the electronegative $\mathrm{C}=\mathrm{O}$ in the crystal packing of $\mathbf{1}, \mathbf{2}, \mathbf{3}$, and 4 , with additional anion interactions specific to 2 and 4 [3a]. Of far greater significance was the inner cavity surface potential at the widest point. Here the ESP was found to be $>-12.5 \mathrm{kcal} \mathrm{mol}^{-1}$ more negative, whereas classical $\mathrm{Q}[n]$ are near neutral. This was more obvious as the cavities increased in diameter from $\mathrm{CyB}_{5} \mathrm{Q}[5]$ to $\mathrm{CyB}_{8} \mathrm{Q}[8]$ where the latter had the most negative cavity surface. 
Previous reported decreases in binding affinity of guests cannot, therefore, be explained based on larger portals or spacious cavities; however, the electronic differences are a likely a factor [30].

\section{Highlighted Structural Features for 1, 2, 3, and 4 and Their Outer Surface Interactions}

The solid-state structure of $\mathrm{CyB}_{5} \mathrm{Q}[5] \cdot 7 \mathrm{H}_{2} \mathrm{O}(\mathbf{1})$ was found to be a relatively simple set of stacked cages forming columns side by side as a continuous corrugated sheet (Figure S1). The portals are superimposed upon the $\mathrm{Cy}_{5} \mathrm{Q}[5]$ below but cages of each column are out of register with cages in the adjacent column (A and B, B and C, Figure 2), creating a tube of cavities.

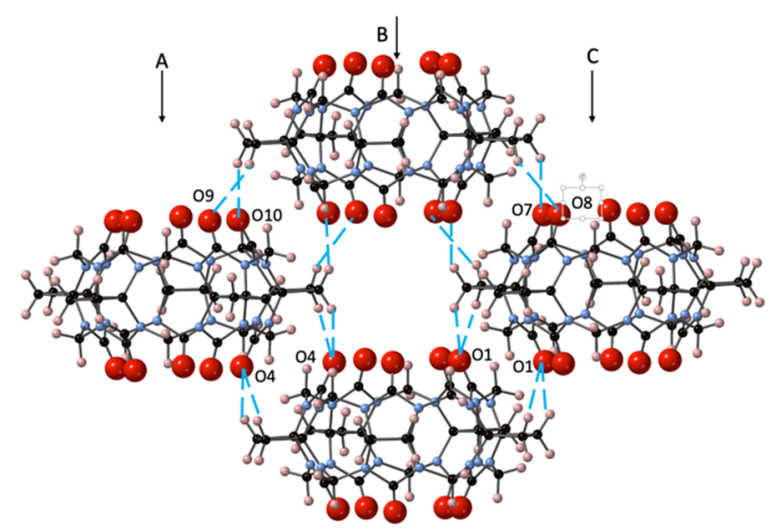

Figure 2. The crystal packing of $\mathrm{CyB}_{5} \mathrm{Q}[5] \cdot 7 \mathrm{H}_{2} \mathrm{O}(\mathbf{1})$ with the dipole-dipole interactions between portal $\mathrm{C}=\mathrm{O}$ and cyclobutano $\mathrm{CH}_{2}$ protons indicated (--) for a set of $4 \mathrm{CyB}_{5} \mathrm{Q}$ [5] representing a segment of columns $\mathrm{A}, \mathrm{B}$, and $\mathrm{C}$. The $\mathrm{H}_{2} \mathrm{O}$ was omitted for clarity.

The asymmetric unit structure $\mathrm{CyB}_{5} \mathrm{Q}[5] \cdot 7 \mathrm{H}_{2} \mathrm{O}$ contains a water molecule in each portal $(\mathrm{O} 1 \mathrm{~W}$ and $\mathrm{O} 2 \mathrm{~W})$ but none in the cavity (Figure S2a). The remaining $5 \mathrm{H}_{2} \mathrm{O}$ completes a H-bonding network that helps to link each $\mathrm{CyB}_{5} \mathrm{Q}[5]$ cage (Figure S2b and Table S1). However, the most significant driving force in the crystal packing arises through dipoledipole interaction between the portal $\mathrm{C}=\mathrm{O}$ and the cyclobutano $\mathrm{CH}_{2}$ protons. The lacing together of columns $\mathrm{A}, \mathrm{B}$, and $\mathrm{C}$ is affected with 16 associated interactions, as shown for set of four $\mathrm{CyB}_{5} \mathrm{Q}[5]$ (Figure 2). The specific proton connections are $\mathrm{O} 1-\mathrm{H} 4 \mathrm{~A}$ and $\mathrm{H} 3 \mathrm{~B}$, O4-H27B and H28A, O7-H4B, O8-H3A, O9-H28B, and O10-H27A (distances 2.56, 2.54, $2.59,2.51,2.38,2.81,2.84$, and $2.37 \AA$, respectively). Hence, there are significant dipoledipole interactions between the electronegative $\mathrm{C}=\mathrm{O}$ and electropositive cyclobutano $\mathrm{CH}_{2}$.

The primary driving force for the crystal packing of $\mathrm{CyB}_{6} \mathrm{Q}[6]$ in the crystal $\mathrm{CyB}_{6} \mathrm{Q}[6]$. $2 \mathrm{Cl}^{-} \cdot 2\left(\mathrm{H}_{3} \mathrm{O}^{+}\right) \cdot 14 \mathrm{H}_{2} \mathrm{O}(2)$ obtain from dilute $\mathrm{HCl}$ was also strongly influenced by the outer surface interaction of the partially positive $\mathrm{CH}_{2}$ protons of the cyclobutano substituent. This is reflected in the short distances between O6-H7B, O4-H23A, and Cl1-H7A (2.44, 2.75 , and $2.74 \AA$, respectively). Slightly longer interactions between $\mathrm{Cl} 1-\mathrm{H} 22 \mathrm{~A}$ and $\mathrm{H} 15$ (2.94 and $3.00 \AA$ ) were also found. The portals $\mathrm{O} 4$ and $\mathrm{O} 6$ are directly connected to H23A and H7B of their cyclobutano nearest $\mathrm{CyB}_{6} \mathrm{Q}[6]$ neighbor (Figure 3). 


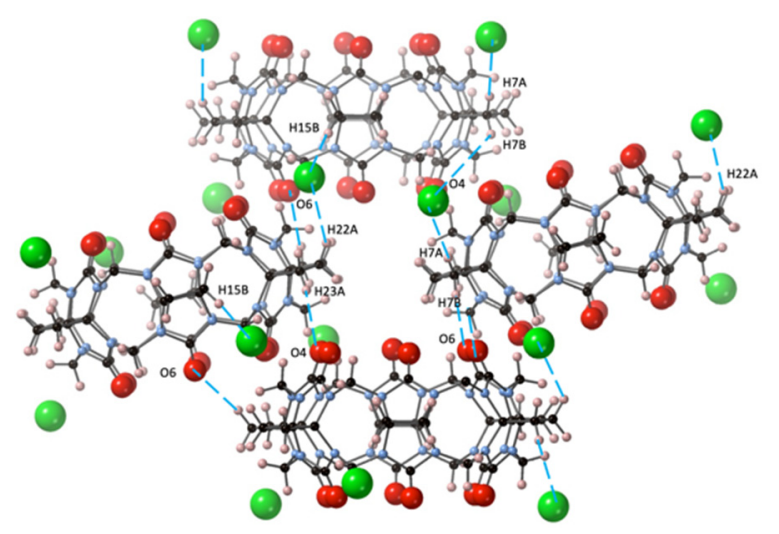

Figure 3. In structure 2, the $\mathrm{CyB}_{6} \mathrm{Q}[6]$ outer surface dipole connections (- $)$ are shown between $\mathrm{C}=\mathrm{O}$ and cyclobutano $\mathrm{CH}_{2}$ and these same protons and the $\mathrm{Cl}^{-}$ion (green).

The third largest homologue $\mathrm{CyB}_{7} \mathrm{Q}[7]$ was concentrated through chromatography and crystallized from dilute $\mathrm{HCl}$ solutions with very slow evaporation to afford $\mathrm{CyB}_{7} \mathrm{Q}[7] \cdot 12 \mathrm{H}_{2} \mathrm{O}$ (3) (Figure 4). Interestingly, no $\mathrm{Cl}^{-}$ions were retained in these structures. The $\mathrm{CyB}_{7} \mathrm{Q}[7]$ are superimposed in closely stacked arrangements of columns, with significant quantities of water molecules congregated in line with and in close proximity to their portals. The interstitial portal spaces between each $\mathrm{CyB}_{7} \mathrm{Q}[7]$ had four water molecules sandwiched in these locations. One space was occupied by $\mathrm{O} 3 \mathrm{~W}, \mathrm{O} 4 \mathrm{~W}$, and $\mathrm{O} 5 \mathrm{~W}$ with $\mathrm{O} 4 \mathrm{~W}$ duplicated and $\mathrm{O} 6 \mathrm{~W}, \mathrm{O} 7 \mathrm{~W}$, and O8W occupying the opposite space with O7W duplicated (Figure S4). Surprisingly, no water molecules were found in the cavity, only just inside the portal. The remaining water $\mathrm{O} 1 \mathrm{~W}$ and $\mathrm{O} 2 \mathrm{~W}$ duplicated and sat toward the edges of two shared portals. The prime dipole driving force for close-packed column formation appeared to be the connections between the $\mathrm{C}=\mathrm{Os}$ and the protons of cyclobutano $\mathrm{CH}_{2}$ of the closest $\mathrm{CyB}$. Q[7] in a neighboring column (O1-H3B and O7-H17A, 2.72 and $2.94 \AA$, respectively).
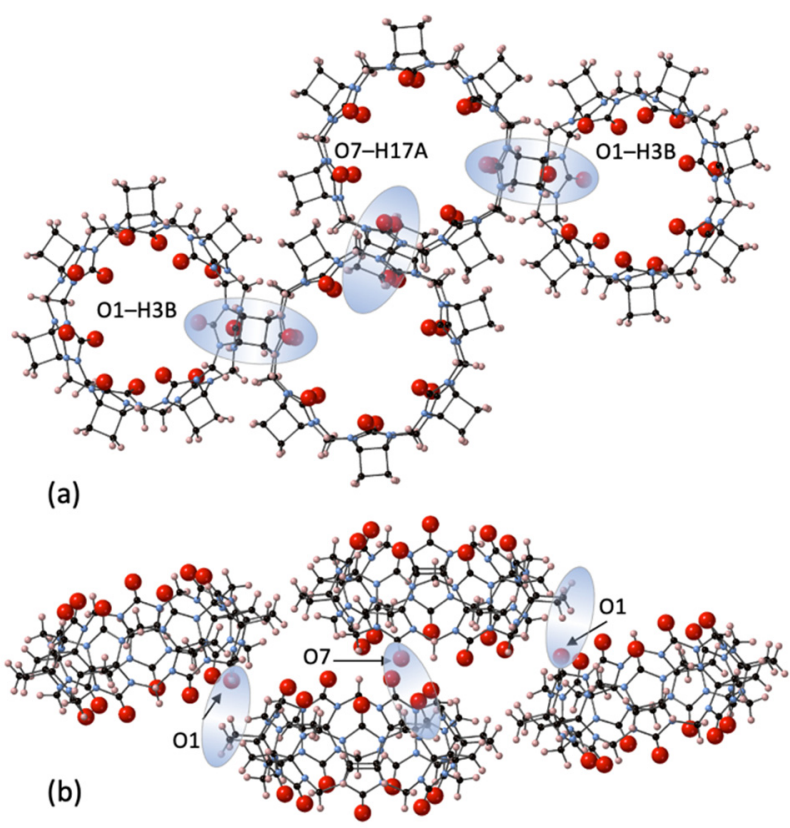

Figure 4. A segment of the crystal structure 3 showing the inter-column connections that are the predominant structural features as seen from (a) the portal view and (b) from the side view, of the $\mathrm{CyB}_{7} \mathrm{Q}[7]$ stacked columns, showing the dipole-dipole interactions between O1-H3B and O7-H17A (shaded highlights).

The largest homologue $\mathrm{CyB}_{8} \mathrm{Q}[8]$ was successfully crystallized with the assistance of a chlorozincate anion, which resulted in the crystals $\mathrm{CyB}_{8} \mathrm{Q}[8] \cdot\left(\mathrm{ZnCl}_{3} \cdot \mathrm{H}_{2} \mathrm{O}\right)^{-} \cdot \mathrm{H}_{3} \mathrm{O}^{+} \cdot 10 \mathrm{H}_{2} \mathrm{O}$ 
(4). The $\mathrm{CyB}_{8} \mathrm{Q}[8]$ cages were found to be knitted together by the $\left[\mathrm{ZnCl}_{3} \mathrm{H}_{2} \mathrm{O}\right]^{-}$anion into an apparent honeycomb structure (Figure 5a). Multiple close associations with the $\left[\mathrm{ZnCl}_{3} \mathrm{H}_{2} \mathrm{O}\right]^{-}$anion and the electropositive cyclobutano protons with contact distances of $\sim 2.8 \AA$ created a cluster of $3 \mathrm{xCyB}_{8} \mathrm{Q}[8]$ s around a single anion (Figure $5 \mathrm{~b}$ ). The second $\left[\mathrm{ZnCl}_{3} \mathrm{H}_{2} \mathrm{O}\right]^{-}$anion shown and the fourth $\mathrm{CyB}_{8} \mathrm{Q}[8]$ was the beginning to the next stacked layer. The porosity of the solid-state structure was obvious with the omission of $\mathrm{H}_{2} \mathrm{O}$. In addition, the portals and cavities were not obstructed by anions (Figure $5 \mathrm{a}$ ). $\mathrm{H}_{2} \mathrm{O}$ was found $\mathrm{H}$-bonded to the $\mathrm{C}=\mathrm{O}$ just inside the portals, close to the $\mathrm{Cl}$ of the anion and between the outer surfaces of the $\mathrm{CyB}_{8} \mathrm{Q}[8]$ (Figure S5). The primary driving force for packing appeared to be the ion-dipole interaction between electropositive protons on the outer surface and the anion. However, close portal $\mathrm{C}=\mathrm{O}$ to cyclopentano $\mathrm{CH}_{2}$ interactions were found between O5-H60A, O13-H5B, and a slightly longer interaction O15-H4A, 2.74, 2.64, and $2.98 \AA$, respectively.

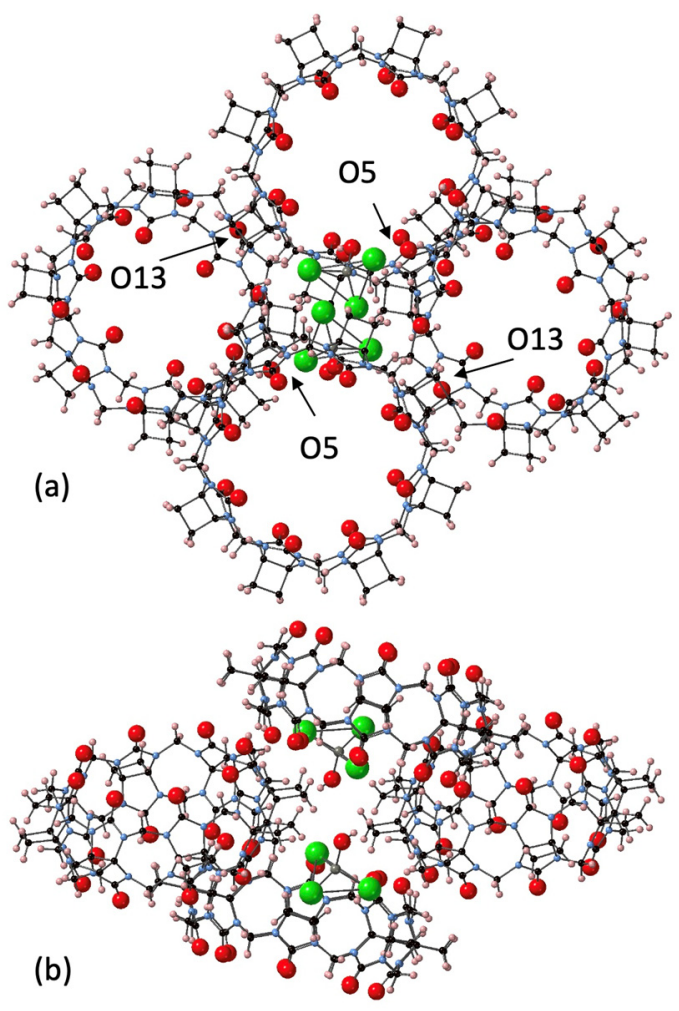

Figure 5. Views of the crystal packing of 4. The close association of the cyclobutano $\mathrm{CH}_{2}$ outer surface of $\mathrm{CyB}_{8} \mathrm{Q}[8]$ with the $\left[\mathrm{ZnCl}_{3} \mathrm{H}_{2} \mathrm{O}\right]^{-}$anion is shown. (a) $\mathrm{O} 5$ and $\mathrm{O} 13$ are labelled and have close interactions with cyclobutano $\mathrm{CH}_{2}$. (b) The same structural unit with a side view after rotating vertically $90^{\circ}$. All water molecules were omitted for clarity, except $\mathrm{Zn}$-coordinated $\mathrm{H}_{2} \mathrm{O}$.

Collectively, each homologue was found to have significant outer surface interactions between the electropositive cyclobutano $\mathrm{CH}_{2}$ and the electronegative portal $\mathrm{C}=\mathrm{O}$ and /or the anions $\mathrm{Cl}^{-}$or $\left[\mathrm{ZnCl}_{3} \mathrm{H}_{2} \mathrm{O}\right]^{-}$that contribute to the crystal packing of each structure. The directionality of the $\mathrm{CH}_{2}$ relative to the cavities favors the formation of near-parallel cavity columns, which contrasts with the classical $\mathrm{Q}[n]$. The equatorial protons of classical $\mathrm{Q}[n]$ protrude at $90^{\circ}$ relative to the cavity axis and, therefore, allow direct portal interaction with a near neighbor, leading to orientation of cavities perpendicular to each other.

The electropositive outer surface of the family of $\mathrm{Cy}_{5-8} \mathrm{Q}[5-8]$ was supported by ESP calculations (Figure 6). However, compared to the classical Q[5-8], two distinct differences were found, which are highlighted in Table 2 [4]. The first was that the outer equatorial surface was less positive by $10-12 \mathrm{kcal} \mathrm{mol}^{-1}$ compared to ESPs for the classical Q[5-8] but clearly sufficiently positive to favor interactions with the electronegative $\mathrm{C}=\mathrm{O}$ in the 
crystal packing of 1, 2, 3, and 4 with additional anion interactions specific to 2 and 4 [3a]. The second, but more important, difference is at the inner cavity surface at the widest point. Here the ESP $>-12.5 \mathrm{kcal} \mathrm{mol}^{-1}$ was more negative, whereas classical $\mathrm{Q}[n]$ were near to neutral. The visible color change of the ESP map of the cavity surfaces from yellow to nearly all red was obvious as the cavities increased in diameter, with $\mathrm{CyB}_{8} \mathrm{Q}[8]$ being the most negative (Figure 6).

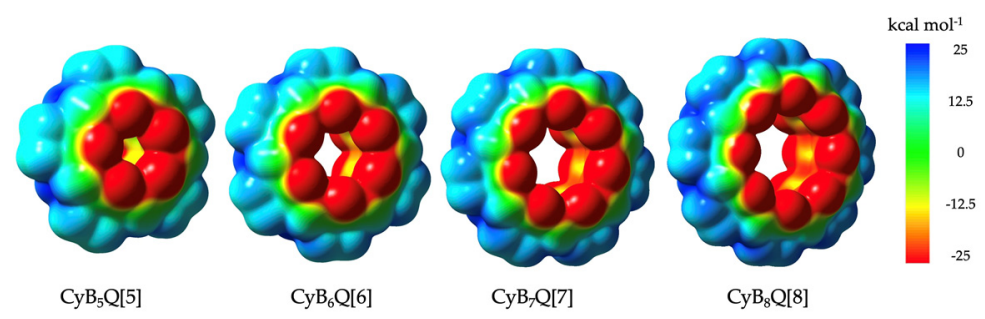

Figure 6. Electrostatic potential maps (ESPs) for $\mathrm{CyB}_{5} \mathrm{Q}[5], \mathrm{CyB}_{6} \mathrm{Q}[6], \mathrm{CyB}_{7} \mathrm{Q}[7]$, and $\mathrm{CyB}_{8} \mathrm{Q}[8]$, respectively.

Table 2. Relative ESP mapped energies $\left(\mathrm{kcal} \mathrm{mole}^{-1}\right)$ of classical $\mathrm{Q}[n]$ and $\mathrm{CyB}_{n} \mathrm{Q}[n]$ comparing the surfaces of their cavities, equatorial regions, and portals.

\begin{tabular}{cccc}
\hline & Cavity C-C & Equatorial CH/CH2 & Portal C=O \\
\hline $\mathrm{Q}[n]$ & $0 \pm 5$ & +25 & $-25[4]$ \\
$\mathrm{CyB}_{n} Q[n]$ & -12.5 & +12.5 & -25 \\
\hline
\end{tabular}

A feature not discussed so far that could impact the size of the cavities of $\mathrm{CyB}_{5-8} \mathrm{Q}[8]$ is the $\beta^{\circ}$ angle of the cis-fused imidazolidinone rings of the glycoluril moieties. As an average this was found to be $\sim 0.8^{\circ}$ wider than classical Q[5-8]. As a poignant comparison, the six smaller homologues of $\mathrm{Me}_{10-12} \mathrm{Q}[5-6]$, classical Q[5-6], and $\mathrm{CyB}_{5-6} \mathrm{Q}[5-6]$ (Figure $1 \mathrm{R}=\mathrm{Me}$, $\mathrm{H}$ and $\mathrm{CyB}$, respectively) each had differences, with the most striking occurring between the Me-substituted examples compared to the other two types $\left(\beta=112.17\right.$ and $112.84^{\circ}$ for Me substitution, respectively, $\beta>3^{\circ}$ wider angle, Table 3 ). This difference occurred as a function of the substituent carried at the cis-fused junction of the glycoluril moiety.

Table 3. A comparison of the $\beta$ angle of the cis-fused junction of the glycoluril moieties of classical $\mathrm{Q}[n], \mathrm{Me}_{2 n} \mathrm{Q}[n]$, and $\left.\mathrm{CyB}_{n} \mathrm{Q}[n]\right)$, with the difference shown as $\Delta^{\circ}$.

\begin{tabular}{ccccc}
\hline & $\begin{array}{c}\text { Average } \beta^{\circ} \\
\mathbf{N}-\mathrm{C}-\mathbf{N}\end{array}$ & & $\begin{array}{c}\left(\mathrm{CyB}_{n} \mathrm{Q}[n]-\mathrm{Q}[n]\right) \\
\boldsymbol{\Delta}^{\circ}\end{array}$ & $\begin{array}{c}\left(\mathrm{CyB}_{n} \mathrm{Q}[n]-\mathbf{M e}_{2 n} \mathrm{Q}[n]\right) \\
\boldsymbol{\Delta}^{\circ}\end{array}$ \\
\hline $\mathrm{Me}_{10} \mathrm{Q}[5]$ & 112.17 & {$[36]$} & & \\
$\mathrm{Q}[5]$ & 115.14 & {$[33]$} & 0.84 & 3.81 \\
$\mathrm{CyB}_{5} \mathrm{Q}[5]$ & 115.98 & & & \\
\hline $\mathrm{Me}_{12} \mathrm{Q}[6]$ & 112.84 & {$[37]$} & & 2.99 \\
$\mathrm{Q}[6]$ & 114.63 & {$[34]$} & 1.2 & -1 \\
$\mathrm{CyB}_{6} \mathrm{Q}[6]$ & 115.83 & & & \\
\hline $\mathrm{Q}[7]$ & 114.65 & {$[33]$} & 0.55 & -1 \\
$\mathrm{CyB}_{7} \mathrm{Q}[7]$ & 115.2 & & & \\
\hline $\mathrm{Q}[8]$ & 114.51 & {$[35]$} & 0.7 & \\
$\mathrm{CyB}_{8} \mathrm{Q}[8]$ & 115.21 & & &
\end{tabular}

${ }^{1}$ The synthesis of $\mathrm{Me}_{2 \mathrm{n}} \mathrm{Q}[n] n=7$ or 8 is not known.

The findings above underline the significance of the $\beta^{\circ}$ angle of the glycoluril precursors (such as the diethers, Figure 1 RHS) to the synthesis of fully substituted higher homologues.

In addition to ESP theory, we also calculated the dihedral $\beta^{\circ}$ of the precursor glycoluril diethers $\mathrm{R}=\mathrm{Me}, \mathrm{CyH}, \mathrm{CyP}$, and $\mathrm{CyB}$ and where $\mathrm{R}=\mathrm{H}$, the latter an unknown compound 
(Figure 1). The interest here was 2-fold: to determine through calculation the angle $\beta^{\circ}$ for the diethers including $\mathrm{R}=\mathrm{H}$, which has no measurable data available, and, secondly, to compare theoretical values with those previously measured. A good fit of theory to measure would also support future applications as a predictive tool to identify suitable glycoluril candidates for the synthesis of higher homologues. The theoretical values compared well for the three cyclo-substituted examples and $\mathrm{R}=\mathrm{Me}$, as shown in Table 4. However, $\mathrm{R}=\mathrm{CyB}$ and Me were slightly over estimated.

Table 4. A comparison of calculated and measured dihedral angles $\beta^{\circ}$ for the different substituted glycoluril diethers shown in Figure 1.

\begin{tabular}{ccc}
\hline Substituent $\mathbf{R}=$ & Calculated $\boldsymbol{\beta}^{\circ}$ & Measured $\boldsymbol{\beta}^{\circ}[29,30]$ \\
\hline $\mathrm{H}$ & 111.9 & - \\
$\mathrm{CyB}$ & 112.8 & 111.77 \\
$\mathrm{CyP}$ & 110.5 & 110.08 \\
$\mathrm{CyH}$ & 109.8 & 109.31 \\
$\mathrm{Me}$ & 110.2 & 108.88 \\
\hline
\end{tabular}

The calculated trend toward a wider angle from $\mathrm{CyH}$ to $\mathrm{CyB}$ (6-4 membered ring substituents) and a consistency with the measured angle is encouraging and potentially could be applied to future theoretical glycoluril diethers and ultimately to the synthesis of newly substituted $\mathrm{Q}[n]$ families. The measured trend is also consistent in $\mathrm{Q}[n]$ derivatives, although the angles are wider due the involvement of eight-membered rings joining neighboring glycoluril moieties as opposed to six-membered rings for the glycoluril diethers.

\section{Materials and Methods}

Starting materials were purchased from commercial suppliers and used without further purification. $\mathrm{CyB}_{5-8} \mathrm{Q}[5-8]$ were prepared in accordance with the literature method [30]. NMR spectra were identical to those previously reported.

\subsection{Purification of $\mathrm{CyB}_{5} \mathrm{Q}[5] \cdot 7 \mathrm{H}_{2} \mathrm{O}(\mathbf{1})$ and $\mathrm{CyB}_{6} \mathrm{Q}[6] \cdot 2 \mathrm{Cl}^{-} \cdot 2\left(\mathrm{H}_{3} \mathrm{O}^{+}\right) \cdot 14 \mathrm{H}_{2} \mathrm{O}(2)$}

The crude mixture of $\mathrm{CyB}_{n} \mathrm{Q}[n]$ was obtained as a solid (2.76 g), which also contained $\mathrm{LiCl}(0.1 \mathrm{~g})$ as part of the reaction process. Distilled water $(50 \mathrm{~mL})$ was added, and the mixture was heated to dissolve the bulk of the material. The undissolved material (1.15 g) was collected by filtration and the filtrate was set aside at RT, over a period of days, which resulted in successive quantities of precipitate, also collected by filtration $(0.81 \mathrm{~g})$. The undissolved material and the collected precipitates were combined. The total of the collected solids $(1.96 \mathrm{~g})$ were then completely dissolved in distilled water $(30 \mathrm{~mL})$ following the addition of $\mathrm{HCl} 32 \%$ (8-10 drops). After 30 days at RT, crystals of 1 were obtained $(0.15 \mathrm{~g})$. The filtrate was then set aside at RT for 40 days, which yielded crystals of $2(0.08 \mathrm{~g})$.

\subsection{Purification of $\mathrm{CyB}_{7} \mathrm{Q}[7] \cdot 12 \mathrm{H}_{2} \mathrm{O}(3)$ and $\mathrm{CyB} 8 \mathrm{Q}[8] \cdot\left(\mathrm{ZnCl}_{3} \cdot \mathrm{H}_{2} \mathrm{O}\right)^{-} \cdot \mathrm{H}_{3} \mathrm{O}^{+} \cdot 10 \mathrm{H}_{2} \mathrm{O}(4)$}

The filtrate above, obtained from the solution remaining after the collection of the cocrystallized $\mathrm{CyB}_{5-6} \mathrm{Q}[5-6]$, was evaporated to dryness and the residue ( $\left.0.85 \mathrm{~g}\right)$ was subjected to silica gel column chromatography eluting with a mixture of $\mathrm{HCO}_{2} \mathrm{H} / \mathrm{AcOH} / \mathrm{EtOH}$ (1:5:0.1). After the early fractions were clear of remaining $\mathrm{CyB}_{5-6} \mathrm{Q}$ [5-6] (as determined by tlc), the eluant was changed to $\mathrm{HCO}_{2} \mathrm{H} / \mathrm{AcOH}(1: 2)$. Fractions of predominantly $\mathrm{CyB}_{7} \mathrm{Q}$ [7] were combined and the solvent was evaporated in vacuo. Modification of the eluant ratio to 1:1 gave $\mathrm{CyB}_{8} \mathrm{Q}[8]$-rich fractions, which were also combined, and the solvent was evaporated.

The solid residue from the $\mathrm{CyB}_{7} \mathrm{Q}[7]$-rich fractions were dissolved in diluted $\mathrm{HCl}$ $0.03 \mathrm{M}(2 \mathrm{~mL})$ and set aside for $\sim 50$ days with slow evaporation to obtain single crystals of 3. The residue from the $\mathrm{CyB}_{8} \mathrm{Q}[8]$-rich fractions were also dissolved in diluted $\mathrm{HCl} 0.03 \mathrm{M}$ $(2 \mathrm{~mL})$ with added $\mathrm{ZnCl}_{2}(0.3 \mathrm{~g})$. After a similar time period with slow evaporation, single crystals of 4 were obtained. 


\subsection{X-ray Crystallography}

X-ray crystal data for complexes 1-4 were collected on a Rigaku Oxford Diffraction Supernova Dual Source (Oxford Diffraction Ltd., Abingdon, England) $\mathrm{Cu}$ at zero equipped with an AtlasS2 CCD using Mo-K $\alpha$ radiation. Lorentz polarization and absorption corrections were applied. Structural solutions and full-matrix least-squares refinements based on $\mathrm{F}^{2}$ were performed using the SHELXT-14 and SHELXL-14 program packages, respectively. All non-hydrogen atoms were refined anisotropic thermal parameters. Analytical expressions of the neutral atom-scattering factors were employed and anomalous dispersion corrections were incorporated. A summary of the crystallographic data, collection conditions, and refinement parameters for complexes 1-4 are listed in Table 5. Crystallographic data (excluding structure factors) for the structure reported in this paper have been deposited with the Cambridge Crystallographic Data Centre as deposition Nos. CCDC $1997294,2050695,2050988$, and 20501000. Copies of the data can be obtained free of charge on application to CCDC, 12 Union Road, Cambridge CB2 1EZ, UK (Fax: +44 1223/336 033; e-mail: deposit@ccdc.cam.ac.uk).

Table 5. Summary of single crystal X-ray diffraction results for compounds 1-4.

\begin{tabular}{|c|c|c|c|c|}
\hline & 1 & 2 & 3 & 4 \\
\hline Formula & $\mathrm{C}_{40} \mathrm{H}_{54} \mathrm{~N}_{20} \mathrm{O}_{17}$ & $\mathrm{C}_{48} \mathrm{H}_{82} \mathrm{Cl}_{2} \mathrm{~N}_{24} \mathrm{O}_{28}$ & $\mathrm{C}_{56} \mathrm{H}_{80} \mathrm{~N}_{28} \mathrm{O}_{26}$ & $\mathrm{C}_{64} \mathrm{H}_{89} \mathrm{Cl}_{3} \mathrm{~N}_{32}-\mathrm{O}_{28} \mathrm{Zn}$ \\
\hline FW & 1087.03 & 1514.27 & 1561.48 & 1926.39 \\
\hline $\mathrm{T} / \mathrm{K}$ & 100 & 293 & 293 & 110 \\
\hline Crystal system & triclinic & monoclinic & orthorhombic & triclinic \\
\hline Space group & P-1 & $\mathrm{P} 12_{1} / \mathrm{c} 1$ & P nma & P-1 \\
\hline a $[\AA]$ & $12.3691(7)$ & $11.3747(6)$ & $13.4181(8)$ & 15.8972(12) \\
\hline $\mathrm{b}[\AA]$ & $14.8265(17)$ & 17.0087(7) & 23.0795(18) & $18.3412(14)$ \\
\hline$c[\AA]$ & $17.6974(10)$ & 17.4352(7) & 28.3746(19) & $20.3221(14)$ \\
\hline$\alpha\left[{ }^{\circ}\right]$ & $75.361(7)$ & 90 & 90 & $78.560(6)$ \\
\hline$\beta\left[^{\circ}\right]$ & $89.902(5)$ & $93.656(4)$ & 90 & $75.665(6)$ \\
\hline$\gamma\left[^{\circ}\right]$ & $74.370(7)$ & 90 & 90 & $70.009(7)$ \\
\hline $\mathrm{V}\left[\AA^{3}\right]$ & $3016.4(4)$ & $3366.3(3)$ & 8787.1(10) & $5352.8(7)$ \\
\hline $\mathrm{Z}$ & 2 & 2 & 4 & 2 \\
\hline $\mathrm{R}[\mathrm{I}>2 \sigma(\mathrm{I})]^{1}$ & 0.1181 & 0.0877 & 0.0954 & 0.0912 \\
\hline$w R[I>2 \sigma(I)]^{2}$ & 0.3249 & 0.2500 & 0.2575 & 0.2256 \\
\hline
\end{tabular}

\subsection{Theoretical Method}

The theoretically calculated dihedral angle $\beta^{\circ}$ of the fused imidazolidinone rings at the concave face for each glycoluril diether and the ESP was determined for $\mathrm{CyB}_{5-8} \mathrm{Q}[5-8]$ using the B3LYP / 6-311G (d, p) level of theory from Gaussian 09 calculations.

\section{Conclusions}

The purification and separation of substituted Q homologues is always a challenge and here we were able to separate the two more difficult larger homologues on silica gel using polar solvent gradients.

The structural parameters for the family of $\mathrm{CyB}_{5-8} \mathrm{Q}[5-8]$ are similar to classical Q[5-8] in their portal and cavity dimensions. Electronically, however, significant electronegative potentials were found within the cavities of $\mathrm{CyB}_{5-8} \mathrm{Q}[5-8]$, unlike the classical $\mathrm{Q}[n]$, which are near neutral based upon comparative ESPs. The outer equatorial surfaces of $\mathrm{CyB}_{5-8} \mathrm{Q}[5-8]$ are relatively positive but not to the same extent as the classical $\mathrm{Q}[n]$. The electropositive nature of the cyclobutano $\mathrm{CH}_{2}$ plays an important role in the crystal packing of each of the four homologues through dipole-dipole interactions. As the electropositive $\mathrm{CH}_{2}$ are nearly aligned with the cavity axes, packing for all four homologues formed parallel or near-parallel cavity columns. 
Given that the physical dimensions are similar to the classical $\mathrm{Q}[n]$, but that the cavity electrostatic potentials are negative, this latter difference could be significant with regard to decreases in the guest binding constants mentioned in the introduction.

Supplementary Materials: The following are available online. Figures S1 and S2: Crystal packing of $\mathrm{Cy}_{5} \mathrm{Q}[5] \cdot 7 \mathrm{H}_{2} \mathrm{O}$ (1) including and excluding structural water. Figure S3: Crystal packing of $\mathrm{CyB}_{6} \mathrm{Q}[6] \cdot 2 \mathrm{Cl}^{-} \cdot 2\left(\mathrm{H}_{3} \mathrm{O}^{+}\right) \cdot 14 \mathrm{H}_{2} \mathrm{O}$ (2) including structural water. Figures $\mathrm{S} 4$ and S5: Crystal packing of $\mathrm{CyB}_{7} \mathrm{Q}[7] \cdot 12 \mathrm{H}_{2} \mathrm{O}$ (3) including structural water. Figure S6: Crystal packing of $\mathrm{CyB}_{8} \mathrm{Q}[8] \cdot\left(\mathrm{ZnCl}_{3} \cdot \mathrm{H}_{2} \mathrm{O}\right)^{-} \cdot \mathrm{H}_{3} \mathrm{O}^{+} \cdot 10 \mathrm{H}_{2} \mathrm{O}(4)$ including structural water. Table S1: The water H-bond parameters of complexes 1-4.

Author Contributions: Investigation and original draft, M.C.; Formal analysis (modelling), N.L.; Formal analysis (crystal data collection and refinement), W.Z.; Writing-review \& editing, A.I.D. All authors have read and agreed to the published version of the manuscript.

Funding: This work was supported by the Qianxinan Science and Technology Bureau Project, Guizhou Province [2021]2021-1-09.

Data Availability Statement: The data is available in a publicly accessible repository.

Conflicts of Interest: The authors declare no conflict of interest.

Sample Availability: Samples of the compounds are available from the authors.

\section{References}

1. Wu, X.; Chen, Y.; Yu, Q.; Li, F.Q.; Lui, Y. A cucurbituril/polysaccharide/carbazole ternary supramolecular assembly for targeted cell imaging. Chem. Commun. 2019, 55, 4343-4346. [CrossRef]

2. Koo, B.; Jun, E.; Liu, H.; Kim, E.J.; Park, Y.Y.; Lim, S.B.; Kim, S.C.; Shin, Y. A biocomposite-based rapid sampling assay for circulating cell-free DNA in liquid biopsy samples from human cancers. Sci. Rep. 2020, 10, 14932. [CrossRef] [PubMed]

3. Huang, Y.; Gao, R.H.; Liu, M.; Chen, L.X.; Ni, X.L.; Xiao, X.; Cong, H.; Zhu, Q.J.; Chen, K.; Tao, Z. Cucurbit[n]uril-based supramolecular frameworks assembled through outer-surface interactions. Angew. Chem. Int. Ed. 2021, 60, 15166-151192. [CrossRef] [PubMed]

4. Jin, Y.; Huang, T.; Zhao, W.; Yang, X.; Meng, Y.; Ma, P. A study on the self-assembly mode and supramolecular framework of complexes of cucurbit[6]urils and 1-(4-methoxyphenyl)piperazine. RSC Adv. 2020, 10, 37369-37373. [CrossRef]

5. Yang, M.-X.; Tang, Q.; Yang, M.; Wang, Q.; Tao, Z.; Xiao, X.; Huang, Y. pH-stimulus response dye-cucurbituril sensor for amino acids in aqueous solution. Spectrochim. Acta A Mol. Biomol. Spectrosc. 2020, 230, 118076. [CrossRef] [PubMed]

6. Olson, J.E.; Braegelman, A.S.; Zou, L.; Webber, M.J.; Camden, J.P. Capture of phenylalanine and Phenylalanine-Terminated Peptides Using a Supramolecular Macrocycle for Surface-Enhanced Raman Scattering Detection. Appl. Spectrosc. 2020, 74, 1374-1383. [CrossRef] [PubMed]

7. Liu, M.; Kan, J.; Yao, Y.; Zhang, Y.; Bian, B.; Tao, Z.; Zhu, Q.; Xiao, X. Facile preparation and application of luminescent cucurbit[10]uril-based porous supramolecular frameworks. Sens. Actuators B Chem. 2019, 283, 290-297. [CrossRef]

8. Li, Q.; Sun, J.; Zhou, J.; Hua, B.; Shao, L.; Huang, F. Barium cation-responsive supra-amphiphile constructed by a new twisted cucurbit[15]uril/paraquat recognition motif in water. Org. Chem. Front. 2018, 5, 1940-1944. [CrossRef]

9. Cheng, Q.; Cao, Z.; Hao, A.; Zhao, Y.; Xing, P. Fluorescent imprintable hydrogels via organic/inorganic supramolecular coassembly. ACS Appl. Mater. Interfaces 2020, 12, 15491-15499. [CrossRef]

10. Shan, P.-H.; Zhao, J.; Deng, X.-Y.; Lin, R.-L.; Bian, B.; Tao, Z.; Xiao, X.; Liu, J.-X. Selective recognition and determination of phenylalanine by a fluorescent probe based on cucurbit[8]uril and palmatine. Anal. Chim. Acta 2020, 1104, 164-171. [CrossRef] [PubMed]

11. Zhang, X.; Xie, J.; Xu, Z.; Tao, Z.; Zhang, Q. The interaction between cucurbit[8]uril and baicalein and the effect on baicalein properties. Beilstein J. Org. Chem. 2020, 16, 71-77. [CrossRef]

12. Zhang, X.; Shi, X.; Su, S.; Zhou, G.; Ni, X.-L. Tunable fluorescent pseudorotaxane from axle-length-dependent cucurbit[7]uril complexation. Dyes Pig. 2020, 172, 107785. [CrossRef]

13. Ouari, O.; Bardelang, D. Nitroxide radicals with cucurbit[ $n$ ]urils and other cavitands. Isr. J. Chem. 2018, 58, 343-356. [CrossRef]

14. Tian, X.; Chen, L.X.; Yao, Y.Q.; Chen, K.; Chen, M.-D.; Zeng, X.; Tao, Z. 4-Sulfocalix[4]arene/Cucurbit[7]uril-Based supramolecular assemblies through the outer surface interactions of cucurbit[n]uril. ACS Omega 2018, 3, 6665-6672. [CrossRef] [PubMed]

15. Zhang, Z.-Y.; Chen, Y.; Liu, Y. Efficient Room-Temperature Phosphorescence of a Solid-State Supramolecule Enhanced by Cucurbit[6]uril. Angew. Chem. Int. Ed. 2019, 58, 6028-6032. [CrossRef]

16. Wang, J.; Huang, Z.; Ma, X.; Tian, H. Visible-Light-Excited Room-Temperature Phosphorescence in Water by Cucurbit[8]urilMediated Supramolecular Assembly. Angew. Chem. Int. Ed. 2020, 59, 9928-9933. [CrossRef] [PubMed] 
17. Lian, Z.; Jiang, M.; Qiao, F.; Chen, M.-N.; Wang, R.-Z.; Zhuo, S.; Xing, L.-B. Artificial light-harvesting supramolecular assemblies with different morphology formed by cucurbit[n]urils-based host-guest complexation. J. Photochem. Photobiol. A 2020, $386,112135$. [CrossRef]

18. Li, F.; Wang, M.; Guan, S.; Huang, Z.; Liu, S.; Li, X.; Jiang, X.; Luo, Q.; Xu, J.; Liu, J. Cucurbit[8]uril-based supramolecular polymer nanocapsules as an effective siRNA delivery platform for gene therapy. Polym. Chem. 2019, 10, 5659-5664. [CrossRef]

19. Tang, M.-J.; Liu, M.-L.; Wang, D.-A.; Shao, D.-D.; Wang, H.-J.; Cui, Z.; Cao, X.-L.; Sun, S.-P. Precisely patterned nanostrand surface of cucurbituril[ $n$ ]-based nanofiltration membranes for effective alcohol-water condensation. Nano Lett. 2020, 20, $2717-2723$. [CrossRef] [PubMed]

20. Wu, W.-J.; Wu, F.; Day, A.I. Molecular snuggle and stretch of a tetraammonium chain in the construction of a hetero[4]pseudorotaxane with cyclopentanoQ[6] and classical Q[7]. J. Org. Chem. 2017, 82, 5507-5515. [CrossRef]

21. Li, Z.-F.; Wu, F.; Zhou, F.-G.; Ni, X.-L.; Feng, X.; Xiao, X.; Zhang, Y.-Q.; Xue, S.-F.; Zhu, Q.-J.; Lindoy, L.F.; et al. Approach to 10-unit "bracelet" frameworks based on coordination of alkyl-substituted cucurbit[5]urils and potassium ions. Cryst. Growth Des. 2010, 10, 5113-5116. [CrossRef]

22. Lin, R.-L.; Li, R.; Shi, H.; Zhang, K.; Meng, D.; Sun, W.-Q.; Chen, K.; Liu, J.-X. Symmetrical-tetramethyl-cucurbit[6]uril-driven movement of cucurbit[7]uril gives rise to heterowheel[4]pseudorotaxanes. J. Org. Chem. 2020, 85, 3568-3575. [CrossRef]

23. Wagner, A.; Ly, K.H.; Heidary, N.; Szabó, I.; Földes, T.; Assaf, K.I.; Barrow, S.J.; Sokołowski, K.; Al-Hada, M.; Kornienko, N.; et al. Host-guest chemistry meets electrocatalysis: Cucurbit[6]uril on a Au surface as a hybrid system in CO2 reduction. ACS Catal. 2020, 10, 751-761. [CrossRef] [PubMed]

24. Lin, R.-L.; Dong, Y.-P.; Tang, M.; Liu, Z.; Tao, Z.; Liu, J.-X. Selective recovery and detection of gold with cucurbit[n]urils (n = 5-7). Inorg. Chem. 2020, 59, 3850-3855. [CrossRef]

25. Flinn, A.; Hough, G.C.; Stoddart, F.J.; Williams, D.J. Decamethylcucurbit[5]uril. Angew. Chem. Int. Ed. 1992, 31, 1475-1477. [CrossRef]

26. Sasmal, S.; Sinha, M.K.; Keinan, E. Facile purification of rare cucurbiturils by affinity chromatography. Org. Lett. 2004, 6, 1225-1228. [CrossRef] [PubMed]

27. Zhao, J.; Kim, H.-J.; Oh, J.; Kim, S.-Y.; Lee, J.W.; Sakamoto, S.; Yamaguchi, K.; Kim, K. Cucurbit[n]uril derivatives soluble in water and organic solvents. Angew. Chem. Int. Ed. 2001, 40, 4233-4235. [CrossRef]

28. Jon, S.Y.; Selvapalam, N.; Oh, D.H.; Kang, J.-K.; Kim, S.-Y.; Jeon, Y.J.; Lee, J.W.; Kim, K. Facile synthesis of cucurbit[n]uril derivatives via direct functionalization: Expanding utilization of cucurbit[n]uril. J. Am. Chem. Soc. 2003, 125, 10186-10187. [CrossRef]

29. Wu, F.; Wu, L.-H.; Xiao, X.; Zhang, Y.-Q.; Xue, S.-F.; Tao, Z.; Day, A.I. Locating the cyclopentano cousins of the cucurbit $[n]$ uril family. J. Org. Chem. 2012, 77, 606-611. [CrossRef]

30. Zhao, Y.; Mandadapu, V.; Iranmanesh, H.; Beves, J.E.; Day, A.I. The inheritance angle: A determinant for the number of members in the substituted cucurbit[n] uril family. Org. Lett. 2017, 19, 4034-4037. [CrossRef]

31. Vinciguerra, B.; Zavalij, P.Y.; Isaacs, L. Synthesis and recognition properties of cucurbit[8]uril derivatives. Org. Lett. 2015, 17, 5068-5071. [CrossRef] [PubMed]

32. Huber, G.; Berthault, P.; Nguyen, A.L.; Pruvost, A.; Barruet, E.; Rivollier, J.; Heck, M.-P.; Prieur, B. Cucurbit[5]uril derivatives as oxygen carriers. Supramol. Chem. 2019, 31, 668-675. [CrossRef]

33. Zhang, J.; Ren, H.; Liu, L. Trifluoromethanesulfonate anion-linked supramolecular frameworks of cucurbit[5]uril and cucurbit[7]uril. Chem. Lett. 2010, 39, 1016-1017. [CrossRef]

34. Jeon, Y.-M.; Kim, J.; Whang, D.; Kim, K. Molecular container assembly capable of controlling binding and release of its guest molecules: Reversible encapsulation of organic molecules in sodium ion complexed cucurbituril. J. Am. Chem. Soc. 1996, 118, 9790-9791. [CrossRef]

35. Chen, C.; Ge, W.; Chen, K.; Tao, Z.; Zhang, Y.; Zhu, Q.J. Preparation and adsorption properties of a facile solid cucurbit[8]uril-based porous supramolecular assembly. J. Chem. Res. 2019, 43, 412-418. [CrossRef]

36. Xiao, X.; Zhang, Y.-Q.; Xue, S.-F.; Zhu, Q.-J.; Tao, Z. Crystal Structure of the Decamethylcucurbit[5]uril Complexes with Some Metal Ions. Chin. J. Inorg. Chem. 2009, 25, 596.

37. Cao, L.; Zhang, Y.-Q.; Lin, R.-L.; Liu, J.-X.; Tao, Z. Controllable synthesis of dodecamethylcucurbit[6]uril and its application in separating phenylenediamine isomers. Cryst. Growth Des. 2021, 21, 2993-2999. [CrossRef] 